\title{
The Effect of the Geometric Parameters on the Air Flow Distrib ution Uniformity within the Protonic Ceramic Fuel Cell Stack
}

\author{
J.Q. Dai, M.F. Zhu, H.Z. Zhang, J.P. Liu, D.F. Chen*
}

School of Energy and Power, Jiangsu University of Science and Technology, Zhenjiang 212003, China "E-mail: dfchen@just.edu.cn

Received: 30 June 2021 / Accepted: 12 August 2021 / Published: 10 September 2021

Compared with the traditional fuel cells, the protonic ceramic fuel cell (PCFC) has attracted more and more attentions due to its advantages on intermediate temperature zone. In this paper, the 3D calculated fluid dynamics model for a typical PCFC stack has been developed to study the dependence and sensitivity of the flow distribution uniformity on different geometric parameters. The result shows that although the vapors are generated within the cathode sides, enlarging the manifold radius and decreasing the cell number will greatly increase the air flow distribution uniformity of PCFC stack. Increasing the $a$ factor of PCFC stack will keep decreasing the slop of the air flow distribution line. Thus, it's not like bigger $a$ is better in any case. For a small/large manifold radius, the slops of the flow distributing line will changed greatly/gently, while $a$ factor is adjusted. Although increasing the feed/exhaust header width will increase the flow distributing uniformity over the cathode surface of each PCFC unit, its effect on the flow distribution among the piled PCFC units is negligible.

Keywords: Protonic ceramic fuel cell, Stack structure, Calculated fluid dynamics, 3D large scale modeling

\section{FULL TEXT}

(C) 2021 The Authors. Published by ESG (www.electrochemsci.org). This article is an open access article distributed under the terms and conditions of the Creative Commons Attribution license (http://creativecommons.org/licenses/by/4.0/). 